\title{
Distribution of Endogenous Murine Leukemia Virus DNA Sequences Among Mouse Chromosomes
}

\author{
PAUL JOLICOEUR, ${ }^{1,2 *}$ ERIC RASSART, ${ }^{1}$ CHRISTINE KOZAK, ${ }^{3}$ FRANK RUDDLE, ${ }^{4}$ AND DAVID \\ BALTIMORE ${ }^{5}$
}

Institut de Recherches Cliniques de Montréal ${ }^{1}$ and Département de Microbiologie et d'Immunologie, Université de Montréal, ${ }^{2}$ Montreal, Quebec H2W 1R7, Canada; Laboratory of Viral Diseases, National Institute of Allergy and Infectious Diseases, Bethesda, Maryland $20205^{3}$; Department of Biology, Yale University, New Haven, Connecticut 16520; and Center for Cancer Research and Department of Biology, Massachusetts Institute of Technology, Cambridge, Massachusetts $02139^{5}$

\begin{abstract}
We used mouse-Chinese hamster somatic cell hybrids which lose mouse chromosomes to examine the distribution of murine leukemia virus DNA sequences in the genome of $\mathrm{A} / \mathrm{HeJ}$ mice. We analyzed total cellular DNA from various hybrid clones for the presence of viral sequences by molecular hybridization and used the Southern blot hybridization procedure to identify viral DNA in cellular restriction endonuclease fragments. Our results show that murine leukemia virus DNA sequences are distributed among many mouse chromosomes in this strain. Chromosome 4 was shown to contain murine leukemia virus DNA sequences.
\end{abstract}

The mouse genome contains multiple copies of integrated murine leukemia virus (MuLV) DNA sequences $(7,31,39)$. These integrated viral sequences are transmitted vertically as genetic elements $(7,8,31)$. Inbred and feral strains of Mus musculus $(7,11,13,29)$ and Asian mice, Mus caroli and Mus cervicolor (5), all contain MuLV DNA sequences in their genomes. At least some of these sequences represent structural genes for a variety of biologically distinguishable retroviruses (e.g., ecotropic $\mathbf{N}$ - and $\mathrm{B}$ tropic, xenotropic, and amphotropic MuLV's).

The position of certain of these MuLV DNA sequences in the mouse genome has been determined by genetic analysis. The $A k v-1$ locus, which represents the structural sequences of the ecotropic MuLV of AKR mice, has been mapped on chromosome $7(8,32)$. The Fgv-1 locus of $\mathrm{C} 3 \mathrm{H} / \mathrm{Fg}$ mice has also been mapped on chromosome 7, but is at a site nonallelic with $A k v-1$ (31). The ecotropic MuLV inducibility locus of $\mathrm{BALB} / \mathrm{c}$ mice has been mapped on chromosome 5 (24), and serological assays have identified a locus for the $\mathrm{C} 3 \mathrm{H} / \mathrm{HeJ}$ ecotropic virus on chromosome 5 closely linked but not allelic with the BALB/c ecotropic viral sequences (16). Finally, a locus on chromosome 1 has been identified for xenotropic MuLV inducibility in BALB/c and C57BL/10 mice (23).

The present work was undertaken to study the distribution of MuLV DNA sequences among the chromosomes of $\mathrm{A} / \mathrm{HeJ}$ mice. This strain is representative of low-leukemic, low-virus mice in that infectious virus is rarely observed in vivo and cultured cells are not inducible by 5 -iododeoxyuridine for xenotropic virus and only poorly inducible for ecotropic virus. The chromosomal association of proviral sequences in this strain was examined with a combination of molecular annealing and somatic cell hybridization techniques. The DNA from a series of mouse-Chinese hamster hybrid clones was hybridized to a radioactive DNA probe complementary to B-tropic endogenous MuLV (Btropic $\left[{ }^{3} \mathrm{H}\right] \mathrm{cDNA}$ ) obtained from BALB/c mice. This probe was chosen for its ability to hybridize totally or partially to several viral sequences from biologically distinguishable retroviruses (ecotropic N-tropic MuLV [4, 18, 30], Kirsten MuLV, Rauscher MuLV [4], xenotropic MuLV [4], and amphotropic MuLV [2, 10]). Results of this analysis with a probe of such wide specificity showed that endogenous MuLV DNA sequences in $\mathrm{A} / \mathrm{HeJ}$ mice are located on many different chromosomes.

The kinetics of annealing of BALB/c B-tropic $\left[{ }^{3} \mathrm{H}\right] \mathrm{cDNA}$ with $\mathrm{A} / \mathrm{HeJ}$ cellular DNA is shown in Fig. 1A. The number of viral copies detected with BALB/c B-tropic $\left[{ }^{3} \mathrm{H}\right] \mathrm{cDNA}$ in $\mathrm{A} / \mathrm{HeJ}$ cell DNA was estimated to be 8 to 10 per haploid cell genome. At saturation, 50 to $60 \%$ of $\left[{ }^{3} \mathrm{H}\right]$ cDNA hybridized to A/HeJ cell DNA, but only 40 to $45 \%$ hybridized to NIH/3T3 (NIH) DNA. Cell DNA from BALB/3T3 cells chronically infected with B-Cl-11 virus hybridized to 65 to $70 \%$ of this probe. Therefore, this probe recognizes virus-specific sequences present in $\mathrm{A} / \mathrm{HeJ}$ mouse genomes but absent in other strains such as NIH mice. This result also suggests that some sequences of $\mathrm{B}-\mathrm{Cl}-11\left[{ }^{3} \mathrm{H}\right] \mathrm{cDNA}$ are not present in A/HeJ DNA (7). Annealing of 3 to 5\% was obtained when DNA of the Chinese hamster line 


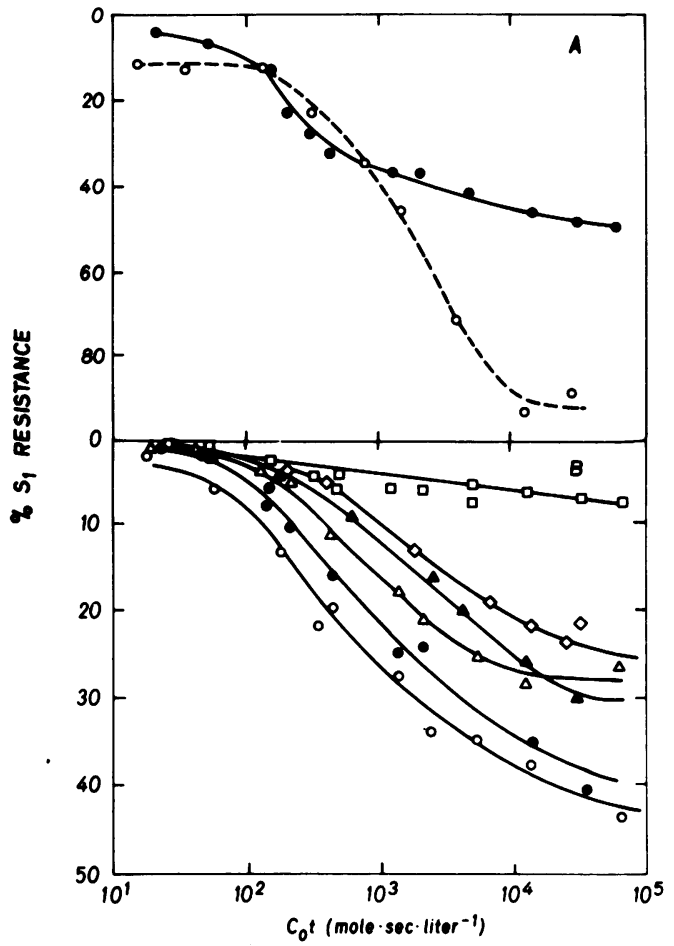

Fig. 1. (A) Hybridization kinetics of viral $\left[{ }^{3} \mathrm{H}\right]$ cDNA with A/HeJ cellular DNA. Cell DNA was extracted and was broken to 350- to 450-nucleotidelong fragments by acid depurination as described before (18). DNA (5 to $10 \mathrm{mg} / \mathrm{ml}$ ) was suspended in $0.01 \mathrm{M}$ Tris-hydrochloride ( $\mathrm{pH}$ 7.5)-0.72 M NaCl$0.05 \%$ sodium dodecyl sulfate-5 mM EDTA. It was mixed in 0.05-ml reaction volumes with $\left.{ }^{3} \mathrm{H}\right] \mathrm{cDNA}$ (600 to 1,000 cpm) and sealed in capillaries for hy. bridization. The mixtures were boiled for $5 \mathrm{~min}$, cooled on ice, and incubated at $67^{\circ} \mathrm{C}$. At different times, capillaries were transferred at $4^{\circ} \mathrm{C}$ to stop the annealing reaction. Hybridization of $\left[{ }^{3} \mathrm{H}\right] c \mathrm{DNA}$ to virus-specific DNA was measured by $\mathrm{S} 1$ nuclease resistance as described previously (18). Results are plotted as a percentage of hybridization versus the input DNA concentration $\left(C_{0}\right)$ multiplied by the time of hybridization (t). The $C_{0} t$ values have been corrected to an equivalent $\mathrm{C}_{0} t$ at an $\mathrm{Na}^{+}$concentration of $0.18 \mathrm{M}$ (3). $\left.{ }^{3} \mathrm{H}\right] \mathrm{cDNA}$ was prepared by incubating cloned $B A L B / c$ endogenous ecotropic B-tropic MuLV (B-Cl-11) virions (17) as described previously (18). This $\left[{ }^{3} H\right] c D N A$ had a specific activity of $2 \times$ $10^{7} \mathrm{cpm} / \mu \mathrm{g}$ and a resistance to $\mathrm{S} 1$ nuclease of $3 \%$. Self-association kinetics of mouse DNA was performed by annealing nonrepetitive ${ }^{3} \mathrm{H}$-labeled $\mathrm{NIH}$ DNA with $A / H e J$ liver DNA. NIH/3T3 cells were labeled for $24 \mathrm{~h}$ with $\left.{ }^{3} \mathrm{H}\right]$ thymidine $(1 \mu \mathrm{Ci} / \mathrm{ml})$. Labeled DNA was extracted, broken by depurination, and hybridized to a $C_{0} t$ value of 600 . After annealing, the DNA was diluted in $0.14 \mathrm{M}$ sodium phosphate buffer containing $0.2 \%$ sodium dodecyl sulfate and loaded on a hydroxyapatite column at $60^{\circ} \mathrm{C}$. Singlestranded DNA was recovered with $0.14 \mathrm{M}$ sodium
E36 was hybridized with $\left[{ }^{3} \mathrm{H}\right] \mathrm{cDNA}$, indicating that few MuLV-related sequences were present in Chinese hamster DNA (Fig. 1B). The relatively good hybridization of A/HeJ cell DNA and the low hybridization of Chinese hamster DNA with BALB/c B-tropic cDNA made it possible to monitor the segregation of virus-specific DNA in different mouse-Chinese hamster hybrid clones.

To quantitate the amount of virus-specific DNA that could be detected in the hybrid clones, artificial mixtures of $\mathrm{A} / \mathrm{HeJ}$ and Chinese hamster DNA were first annealed with viral cDNA (Fig. 1B). As expected, higher hybridization plateau values were obtained with increasing concentrations of A/HeJ DNA. As little as 2 to $5 \%$ of $\mathrm{A} / \mathrm{HeJ}$ cell DNA could be easily detected by this method.

The rate of annealing of B-tropic viral cDNA to the DNA from each mouse-Chinese hamster hybrid clone is shown in Fig. 2. All 13 hybrid clones tested had endogenous MuLV-related sequences. An examination of the mouse chromosome constitution of each of these clones (Table 1) shows that no single mouse chromosome contains all of the MuLV DNA sequences since each of the 20 chromosomes was absent in at least one of the hybrids tested. Therefore, MuLVrelated sequences are distributed among several chromosomes in the mouse genome. This conclusion is also supported by comparing the extent of hybridization in individual clones with increasing numbers of mouse chromosomes. The number of mouse chromosomes identified in metaphase spreads was used to estimate the percentage of murine DNA in each clone (Table 1). Correlation with the annealing kinetics in Fig. 2 shows that with the exception of one hybrid, 13-2AZ, greater annealing with the $\left[{ }^{3} \mathrm{H}\right]$ DNA probe is observed with hybrids having greater numbers of mouse chromosomes.

A comparison of hybridization data and the

phosphate buffer, and double-stranded DNA was eluted with $0.4 M$ sodium phosphate buffer. $\left.{ }^{3} H\right]$ thy. midine-labeled, single-stranded DNA $\left(2.3 \times 10^{5} \mathrm{cpm}\right)$ $\mu g)$ representing nonrepetitive sequences was used for annealing with A/HeJ DNA. Symbols: association with viral $\left.{ }^{3} \mathrm{H}\right] c D N A ; \bigcirc$, self-association with ${ }^{3} \mathrm{H}$ labeled NIH DNA. (B) Association kinetics of viral $\left[{ }^{3} \mathrm{H}\right] c \mathrm{DNA}$ with mixtures of DNA from $A / \mathrm{HeJ}$ mice and Chinese hamsters. A/HeJ mouse DNA was mixed at different ratios with E36 Chinese hamster DNA, and the resulting mixtures were hybridized to $\left[{ }^{3}\right.$ H]cDNA as described above. Symbols: $\square, 0 \%$ mouse DNA and 100\% E36 DNA; $\bigcirc, 2 \%$ mouse DNA; $\triangle, 5 \%$ mouse DNA; $\triangle, 10 \%$ mouse DNA; O, 25\% mouse DNA; O, $50 \%$ mouse DNA. 


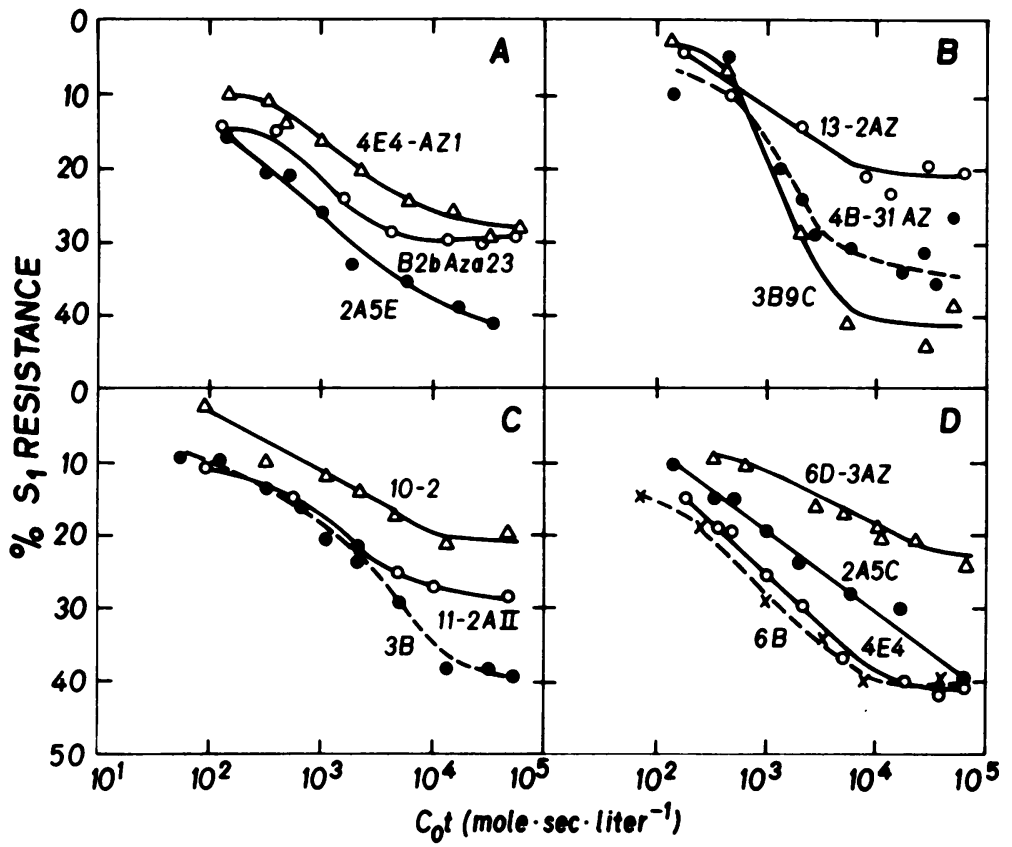

FIG. 2. Association kinetics of viral $\left[{ }^{3} \mathrm{H}\right] c D N A$ with DNA from different mouse-hamster hybrid clones. DNA was extracted from hybrid clones and hybridized to $\left.{ }^{3} \mathrm{H}\right] \mathrm{cDNA}$ as described in the legend to Fig. 1.

mouse chromosomes retained by each clone was used to determine whether specific chromosomes were enriched for such sequences or whether the viral sequences were randomly and uniformly distributed among the 20 mouse chromosomes. In the latter case, a direct correlation would be expected between the number of mouse chromosomes retained and the amount of MuLV-related sequences in each hybrid clone. Deviation from this expectation could be used to identify specific chromosomes which carry viral sequences. The rate of annealing of $\mathrm{MuLV}$ cDNA to each hybrid clone DNA was correlated with the rates obtained for specific mixtures of mouse and hamster DNAs (Fig. 1B) to predict the percentage of mouse DNA present in each clone. This percentage was then compared with the actual percentage of mouse DNA calculated from the fraction of mouse chromosomes observed in metaphase spreads (Table 1). The differences in the actual mouse DNA content and the predicted values show that viral sequences are not uniformly distributed over all mouse chromosomes. One clone (6D3AZ) having only chromosome 4 and another one (10-2) having chromosome 4 and part of the $\mathrm{X}$ chromosome are clearly enriched for viral sequences, their DNA showing more annealing with $\left[{ }^{3} \mathrm{H}\right]$ cDNA than expected by the number of mouse chromosomes retained. Although this apparent enrichment could be an artifact of the exact representation of the chromosomal proviruses in the cDNA probe, this result shows that chromosome 4 does contain viral sequences.

A comparison of chromosome loss and the extent of hybridization in other clones were used in an attempt to identify additional chromosomes which carry viral sequences. Six clones (3B, 3B9C, 6B, 4E4, 2A5E, and 2A5C) retained a large fraction of the total diploid number of mouse chromosomes, and all 20 chromosomes are represented in these clones. The lowest level of hybridization was observed in $2 \mathrm{~A} 5 \mathrm{C}$ and may be correlated with the absence of chromosome 5 and the low frequency of chromosome $15 \mathrm{ob}$ served in this clone. The five remaining clones (11-2A11, B2bAZa23, 4B31AZ, 4E4AZ1, and 132AZ) retained fewer mouse chromosomes and had fewer viral sequences by hybridization. Attempts to induce infectious ecotropic $\mathrm{MuLV}$ from some of these hybrids with iododeoxyuridine showed that only clones $6 \mathrm{~B}$ and $3 \mathrm{~B} 9 \mathrm{C}$, but not 2A5E, B2bAZa23, and 4E4AZ1, produce infectious ecotropic MuLV (Kozak, unpublished observations). This correlates with the loss of chromosome 5 in these clones.

Analysis of the genomes of endogenous viruses of mice by the Southern gel transfer technique and hybridization with a viral cDNA probe has revealed that several EcoRI-cleaved mouse DNA fragments contained viral sequences $(1,36$, 37). To determine whether the presence of some 
TABLE 1. Percentage of cells containing designated chromosome ${ }^{a}$

\% of cells in mouse-hamster hybrid clone:

\begin{tabular}{|c|c|c|c|c|c|c|c|c|c|c|c|c|c|}
\hline Chromosome no. & $10-2$ & $\begin{array}{c}\text { 6D3 } \\
\text { AZ }\end{array}$ & $11-2 A 11$ & B2bAZa23 & 4B31AZ & 4E4AZ1 & 13-2AZ & 3B & $3 B 9 C$ & 2A5E & 6B & 4E4 & 2A5C \\
\hline 1 & & & & & & 20 & 4 & 62 & 26 & 6 & 37 & 40 & 73 \\
\hline 2 & & & 20 & 84 & 40 & 14 & 79 & 72 & 67 & 67 & 89 & 80 & 67 \\
\hline 3 & & & & & & & & 14 & & 78 & 58 & 26 & 73 \\
\hline 4 & 30 & 14 & 57 & & & $-^{b}$ & & 52 & 41 & 15 & 33 & 20 & 40 \\
\hline 5 & & & & & & & & 21 & 63 & & 5 & 35 & \\
\hline 6 & & & & & & & 4 & 62 & 63 & 44 & 42 & 26 & 20 \\
\hline 7 & & & 42 & 53 & 40 & & 54 & 45 & 41 & 52 & 58 & 86 & 60 \\
\hline 8 & & & 23 & & & & 13 & 21 & 39 & 56 & 37 & 20 & 53 \\
\hline 9 & & & & & & & & 52 & 11 & 33 & 42 & 40 & 87 \\
\hline 10 & & & & & & & & 24 & 26 & 74 & 21 & 13 & 47 \\
\hline 11 & & & & & & & & & & & 11 & & \\
\hline 12 & & & & 44 & 24 & 55 & 25 & 41 & 44 & 56 & 52 & 80 & 67 \\
\hline 13 & & & & & & & & 41 & 59 & 19 & 32 & 13 & 13 \\
\hline 14 & & & & & & & & 35 & 78 & 63 & 16 & 20 & 13 \\
\hline 15 & & & 30 & 3 & & 34 & 33 & 17 & 78 & 11 & 52 & 46 & 7 \\
\hline 16 & & & 11 & 47 & 52 & 45 & & 68 & 32 & 67 & 63 & 73 & 80 \\
\hline 17 & & & & & & 24 & 50 & 62 & 56 & 78 & 73 & 53 & 100 \\
\hline 18 & & & & 78 & 11 & & 46 & 48 & 44 & 19 & 47 & 40 & 33 \\
\hline $\begin{array}{l}10 \\
19\end{array}$ & & & & 94 & 52 & 45 & 79 & 52 & 52 & 48 & 79 & 86 & 60 \\
\hline $\mathbf{x}$ & $-^{c}$ & & & & & & & 31 & 30 & 37 & 16 & & 40 \\
\hline $\begin{array}{c}\% \text { of murine } \\
\text { DNA }^{d}\end{array}$ & 1.3 & 0.6 & 6.8 & 9.1 & 12.7 & 8.6 & 19 & 31 & 34.6 & 28 & 34 & 31 & 24.6 \\
\hline $\begin{array}{l}\text { Predicted \% of } \\
\text { murine DNA } \\
\text { from hybrid- } \\
\text { ization with } \\
{\left[{ }^{3} \mathrm{H}\right] \mathrm{cDNA}^{\mathrm{e}}}\end{array}$ & $2-5$ & 2 & $5-10$ & $5-10$ & $10-25$ & 5 & 2 & 25 & $25-50$ & 25 & $50-100$ & 50 & 10 \\
\hline
\end{tabular}

${ }^{a}$ Mouse-Chinese hamster hybrid cell lines were produced by fusion of $\mathrm{A} / \mathrm{HeJ}$ mouse peritoneal macrophages and E36 cells (22). Cells were maintained in Dulbecco-modified Eagle medium supplemented with $10 \%$ calf serum, penicillin $(50 \mathrm{U} / \mathrm{ml})$, and streptomycin $(50 \mu \mathrm{g} / \mathrm{ml})$. Primary hybrids were grown in HAT selective medium (minimal essential medium with $10^{-4} \mathrm{M}$ hypoxanthine, $4 \times 10^{-5} \mathrm{M}$ aminopterin, and $1.6 \times 10^{-5} \mathrm{M}$ thymidine). Secondary clones were either isolated in HAT medium or backselected and maintained in minimal essential medium with 10 to $20 \mu \mathrm{g}$ of 8 -azaguanine per $\mathrm{ml}(21,22)$. Each hybrid clone was characterized for the expression or loss of 18 mouse isozymes for which hamsters and mice have electrophoretically distinguishable forms $(21,22,25)$. Genes for these isozymes have been mapped on 12 mouse chromosomes. Karyotypic analysis of 17 to 100 metaphase spreads of each clone was done by a sequential staining procedure (20). The average number of mouse chromosomes was determined for each hybrid by counting the number of chromosomes in each metaphase plate with brightly fluorescent centromeres after staining with Hoechst 33258 (15). Two independently isolated primary clones and 11 secondary clones derived from 8 independent primary clones were selected for the DNA-DNA annealing studies. Each of these clones retained different complements of mouse chromosomes. Each clone was expanded in culture for DNA extraction. Samples of these hybrid cell populations were retained for isozyme analysis (25) at the same time as DNA extraction and frozen for karyotypic typing (20) two to three generations later.

${ }^{b}$ Isozyme markers of mouse chromosome 4 were expressed, but no intact chromosome 4 was identified.

${ }^{c}$ Expression of mouse hypoxanthine phosphoribosyltransferase, but not $\alpha$-galactosidase, was detected; no intact X chromosome was observed.

${ }^{d}$ Computation of the actual percentage of murine DNA that is present per diploid hybrid cell, assuming that each of the 20 chromosomes represents $5 \%$ of total cell DNA.

- The percentage of mouse DNA in a mouse-hamster hybrid clone which would be predicted by comparing the annealing of hybrid clone DNA and MuLV [ $\left.{ }^{3} \mathrm{H}\right] \mathrm{cDNA}$ with the standard annealing curves of MuLV $\left[{ }^{3} \mathrm{H}\right] \mathrm{cDNA}$ and artificial mixtures of mouse and hamster DNAs (Fig. 1B).

viral fragments could be correlated with individual mouse chromosomes and whether specific viral fragments had been retained in hybrid clones containing only chromosome 4 , we analyzed cell DNA from different hybrid clones by the agarose gel DNA transfer procedure.

We used EcoRI restriction endonuclease to generate DNA fragments from the cellular DNA of some of the hybrid clones. The restriction sites of $E c o R I$ on MuLV DNA sequences of A/ HeJ mouse are not known. It is known, however, that $E c o$ RI does not cleave endogenous BALB/ c ecotropic $\mathrm{N}$ - and B-tropic viruses (Rassart and Jolicoeur, unpublished data) and that it does not cleave AKR endogenous virus (36) and Moloney MuLV (37). EcoRI-generated cellular DNA fragments were separated by agarose gel electrophoresis, and fragments bearing MuLV-related sequences were identified by the Southern DNA transfer procedure (35), using $\left[{ }^{32} \mathrm{P}\right] \mathrm{cDNA}$ as a probe. As shown in Fig. 3, only one major band $\left(2.8 \times 10^{6}\right.$ daltons) and two minor bands $(3.9 \times$ 


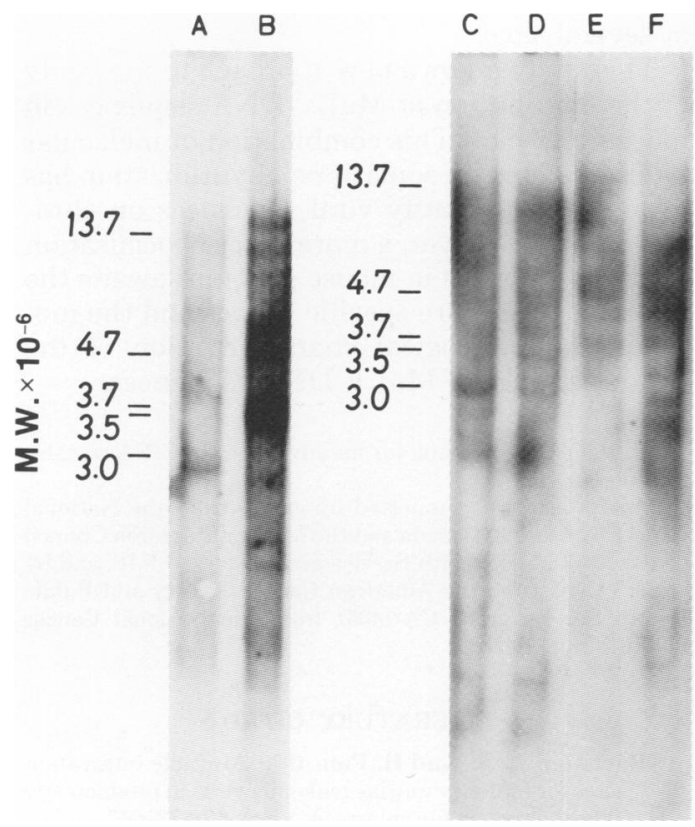

FIG. 3. Detection of MuLV DNA sequences in hy. brid clones after digestion with EcoRI restriction endonuclease. DNA extracted from livers of $A / \mathrm{HeJ}$ mice, from the E36 Chinese hamster cell line, or from various mouse-hamster hybrid clones, was digested to completion with EcoRI endonuclease (Boehringer Mannheim Corp.) in $0.01 \mathrm{M}$ Tris-hydrochloride ( $\mathrm{pH}$ 7.5)-5 $\mathrm{mM} \mathrm{NaCl-1} \mathrm{mM} \mathrm{MgCl}_{\text {. }}$. The reaction was stopped by the addition of EDTA $(0.1 \mathrm{M}$ final concentration), and the mixture was extracted twice with phenol and precipitated with 2 volumes of ethanol at $-20^{\circ} \mathrm{C}$. The DNA fragments were recovered by centrifugation, suspended in water, separated by electrophoresis on a 1\% agarose slab gel (20 by 20 by $0.3 \mathrm{~cm}$ ) in $40 \mathrm{mM}$ Tris-50 $\mathrm{mM}$ sodium acetate-1 $\mathrm{mM}$ EDTA (pH 8.3) for $20 \mathrm{~h}$ at $35 \mathrm{~mA} / \mathrm{gel}$, and transferred onto nitrocellulose filters (Millipore Corp.) (35). DNA fragments were annealed to $3 \times 10^{6}$ to $6 \times 10^{6} \mathrm{cpm}$ of $\left.\Gamma^{32} P\right] c D N A$, and viral DNA was detected by autoradiography as described previously (19). Lambda DNA cleaved with EcoRI was run as marker. [ $\left.{ }^{2} P\right] c D N A$ was prepared by incubating banded cloned $B A L B / c$ endogenous ecotropic B-tropic (B-Cl-11) virions (17) in the presence of $0.05 \mathrm{M}$ Tris-hydrochloride ( $\mathrm{pH}$ 8.3), $0.02 \mathrm{M}$ dithiothreitol, $0.06 \mathrm{M} \mathrm{NaCl}, 6 \mathrm{mM}$ magnesium acetate, $4 \mathrm{mM}$ each $d A T P, d G T P$, and $d T T P, 0.01 \%$ Nonidet $P-40,80 \mu$ of actinomycin $D$ per $\mathrm{ml}, 250 \mu \mathrm{Ci}$ of $\left[\alpha-{ }^{32} \mathrm{P}\right] d \mathrm{CTP}(>300 \mathrm{Ci} / \mathrm{mmol}$; New England $\mathrm{Nu}$ clear Corp.), and $1 \mathrm{mg}$ of calf thymus oligonucleotides as primers (38) in a final volume of $0.5 \mathrm{ml}$. After incubation, the reaction mixture was deproteinized and processed as described previously (18) and ethanol precipitated with $50 \mu \mathrm{g}$ of yeast RNA as carrier. cDNA made with this technique is representative of most of the viral genome as judged by its ability to hybridize with all of the restriction endonuclease fragments of B-Cl-11 viral DNA (Rassart and Jolicoeur, unpublished data). (A) E36, $20 \mu \mathrm{g}$; (B) A/HeJ, $20 \mu g$; (C) B2bAZa23, $20 \mu \mathrm{g}$; (D) 4B31AZ, 20 $\mu \mathrm{g}$ (E) 10-2, $20 \mu \mathrm{g}$; (F) 6D3AZ, $20 \mu \mathrm{g}$.
$10^{6}$ and $6 \times 10^{6}$ daltons) were revealed by this procedure in E36 DNA, in agreement with the low annealing values obtained by liquid hybridization. A/HeJ cellular DNA contains several virus-specific DNA fragments, as reported by Steffen and Weinberg (37) for other mouse strains.

Cellular DNA from hybrid clones which retained only a few mouse chromosomes (4B31AZ and B2bAZa23) showed a somewhat simpler but still complex pattern of virus-specific fragments (Fig. 3C and D), supporting our previous conclusion that MuLV-related sequences are distributed throughout the mouse genome. The complexity and heterogeneity of these bands are such that their precise correlation with individual mouse chromosomes is difficult.

The restriction endonuclease analysis of clones 6D3AZ (having only chromosome 4) and 10-2 (having mainly chromosome 4) showed that DNA from these two clones does contain numerous virus-specific fragments undetected in E36 DNA (Fig. 3E and F). This result supports our previous conclusion that chromosome 4 contains MuLV-related sequences and indicates that these sequences are integrated at several different sites on this chromosome.

This study on the distribution of MuLV DNA sequences in different mouse-Chinese hamster hybrid clones segregating mouse chromosomes indicates that these viral sequences are not located on a single chromosome, but appear to be distributed throughout the mouse genome on many chromosomes. Our data showed that MuLV-related sequences are present on chromosome 4. This finding is of particular interest for two reasons. First, the $F v-1$ gene which controls the expression of ecotropic $\mathrm{N}$ - and B-tropic MuLV has also been mapped on chromosome 4 (33). The relationship of the $F v-1$ locus to endogenous MuLV-related sequences has not yet been determined, but a model suggesting that $F v-1$ codes for viral information has been proposed (41). Second, the distribution of the DNA of the endogenous murine mammary tumor virus has also been studied by Morris and coworkers (27) in some of the same mouse-Chinese hamster hybrid clones. Reassociation kinetics showed that these viral sequences are found on multiple mouse chromosomes, but the Southern blotting procedure identified one band specifically associated with chromosome 4. Further work will be needed to determine whether the chromosomal association of these viral genes is only accidental or biologically significant. Although unlikely, our results cannot exclude the possibility that small undetectable fragments of other chromosomes are responsible for the hybridization to the viral cDNA probe.

The results obtained by a comparison of chro- 
mosome content, reassociation kinetics, and iododeoxyuridine induction in various hybrid clones suggest that chromosome 5 might also contain viral sequences. Chromosome 5 has recently been shown to bear the ecotropic MuLVinducing locus (24) and ecotropic viral sequences (16) of BALB/c mice and an ecotropic viral locus of $\mathrm{C} 3 \mathrm{H} / \mathrm{HeJ}$ mice (16). This chromosome also carries the genetic information which codes for the ecotropic virus-specific cell surface receptor in A/HeJ (34) and other mouse strains (14, 26, $28,34)$ and is necessary for ecotropic MuLV replication (12). Our results did not allow us to establish a clear correlation between the amount of viral sequences and the loss of other chromosomes which have been implicated in viral leukemogenesis in other strains: chromosomes $1,7,11,15$, and 16 . Indeed, it is known that chromosome 1 carries the xenotropic virus-inducing locus in several strains (23). Chromosome 7 carries the viral sequences for the ecotropic virus in $A K R$ mice $(8,32)$ and a virus-inducing locus in $\mathrm{C} 3 \mathrm{H} / \mathrm{Fg}$ mice (31). Chromosomes 11 and 16 carry virus-inducing loci in B10.BR, and AKR mice (C. Kozak and W. P. Rowe, unpublished data). Finally, lymphomas in several strains are commonly found to be trisomic for chromosome $15(6,9,40)$.

The EcoRI-cleaved DNA fragments from A/ HeJ mice contained several endogenous MuLV sequences. This is in agreement with the work of Steffen and Weinberg (37) with other mouse strains. Our results obtained by this procedure with DNA from various hybrid clones are consistent with those obtained by kinetic analysis. However, the multiplicity of endogenous proviruses (as shown by the complex band pattern and the highly diffuse background) made it impossible to correlate the segregation of specific bands with specific chromosomes. The analysis is complicated by the fact that the endogenous sequences present in $\mathrm{A} / \mathrm{HeJ}$ mice have $\mathrm{r}$ t treen fully characterized. Some of these vial sequences may be cleaved by EcoRI, generating viral fragments of various lengths. It is also likely that some endogenous viral sequences may be only partly homologous to the cDNA probe prepared with the ecotropic virus of $\mathrm{BALB} / \mathrm{c}$ mice, resulting in faint bands in the Southern blots. Finally, we cannot exclude the possibility that the viral probe may recognize nonviral mouse sequences and that the individual hybrid clones may have retained additional but undetected fragments of mouse chromosomes. Therefore, it is not possible from our data to identify the predominant set of sequences in each clone. However, it is evident that MuLV-related sequences present on chromosome 4 are integrated at several sites.

This study offers a new approach to the study of the distribution of MuLV DNA sequences in mouse genomes. This combination of molecular hybridization and somatic cell hybridization has been used to identify viral sequences on chromosome 4. However, a more precise localization of viral sequences in mouse genomes awaits the availability of more specific probes and the molecular and biological characterization of the various species of MuLV DNA sequences.

We thank Peter Shank for his advice on the DNA transfer technique.

This project was supported by grants from the National Cancer Institute of Canada and the Medical Research Council to P.J., by Public Health Service grant 09966 to F.R., and by grant VC-4G from the American Cancer Society and Public Health Service grant CA-14051 from the National Cancer Institute to D.B.

\section{LITERATURE CITED}

1. Bacheler, L. T., and H. Fan. 1979. Multiple integration sites for Moloney murine leukemia virus in productively infected mouse fibroblasts. J. Virol. 30:657-667.

2. Barbacid, M., K. C. Robbins, and S. A. Aaronson. 1979. Wild mouse RNA tumor viruses. A nongenetically transmitted virus group closely related to exogenous leukemia viruses of laboratory mouse strains. J. Exp. Med. 149:254-266.

3. Britten, R. J., and D. E. Kohne. 1968. Repeated sequences in DNA. Science 161:529-540.

4. Callahan, R., R. E. Benveniste, M. M. Lieber, and G. J. Todaro. 1974. Nucleic acid homology of murine type C viral genes. J. Virol. 14:1394-1403.

5. Callahan, R., C. J. Sherr, and G. J. Todaro. 1977. A new class of murine retroviruses: immunological and biochemical comparison of novel isolates from Mus cervicolor and Mus caroli. Virology 80:401-416.

6. Chan, F. P. H., J. K. Ball, and F. R. Sergovich. 1979. Trisomy 15 in murine thymomas induced by chemical carcinogens, $\mathrm{X}$-irradiation and an endogenous murine leukemia virus. J. Natl. Cancer Inst. 62:605-610.

7. Chattopadhyay, S. K., D. R. Lowy, N. M. Teich, A. S. Levine, and W. P. Rowe. 1974. Qualitative and quantitative studies of AKR-type murine leukemia virus sequences in mouse DNA. Cold Spring Harbor Symp. Quant. Biol. 39:1085-1101.

8. Chattopadhyay, S. K., W. P. Rowe, N. M. Teich, and D. R. Lowy. 1975. Definitive evidence that the murine C-type virus inducing locus Akv-1 is viral genetic material. Proc. Natl. Acad. Sci. U.S.A. 72:906-910.

9. Dofoku, R., J. L. Biedler, B. A. Spengler, and L. J. Old. 1975. Trisomy of chromosome 15 in spontaneous leukemia of AKR mice. Proc. Natl. Acad. Sci. U.S.A. 72:1515-1517.

10. Gardner, M. B. 1978. Type-C viruses of wild mice: characterization and natural history of amphotropic, ecotropic, and xenotropic MuLV. Curr. Top. Microbiol. Immunol. 79:215-259.

11. Gardner, M. B., J. E. Officer, R. W. Rongey, J. D. Estes, H. C. Turner, and R. J. Huebner. 1971. Ctype RNA tumour virus genome expression in wild house mice. Nature (London) 232:617-620.

12. Gazdar, A. F., H. Oie, P. Lalley, W. W. Moss, J. D. Minna, and W. Francke. 1977. Identification of mouse chromosomes required for murine leukemia virus replication. Cell 11:949-956. 
13. Hartley, J. W., and W. P. Rowe. 1976. Naturally occurring murine leukemia viruses in wild mice: characterization of a new "amphotropic" class. J. Virol. 19:19-25.

14. Hilkens, J., A. Colombatti, M. Strand, E. Nichols, F. H. Ruddle, and J. Hilgers. 1979. Identification of a mouse gene required for binding of Rauscher MuLV envelope gp70. Somatic Cell Genet. 5:39-49.

15. Hilwig, I., and A. Gropp. 1972. Staining of constitutive heterochromatine in mammalian chromosomes with a new fluorochrome. Exp. Cell Res. 75:122-126.

16. Ihle, J. N., D. R. Joseph, and J. J. Domotor. 1979. Genetic linkage of $\mathrm{C} 3 \mathrm{H} / \mathrm{HeJ}$ and $\mathrm{BALB} / \mathrm{c}$ endogenous ecotropic C-type viruses to phosphoglucomutase-1 on chromosome 5. Science 204:71-73.

17. Jolicoeur, P., and D. Baltimore. 1975. Effect of the Fv1 locus on the titration of murine leukemia viruses. $J$. Virol. 16:1593-1598.

18. Jolicoeur, P., and D. Baltimore. 1976. Effect of Fv-1 gene product on proviral DNA formation and integration in cells infected with murine leukemia viruses. Proc. Natl. Acad. Sci. U.S.A. 73:2236-2240.

19. Jolicoeur, P., and E. Rassart. 1980. Effect of $F v-1$ gene product on synthesis of linear and supercoiled viral DNA in cells infected with murine leukemia virus. J. Virol. 33:183-195.

20. Kozak, C. A., J. B. Lawrence, and F. H. Ruddle. 1977. A sequential staining technique for the chromosomal analysis of the interspecific mouse/hamster and mouse/ human somatic cell hybrids. Exp. Cell Res. 105:109117.

21. Kozak, C., E. A. Nichols, and F. H. Ruddle. 1974. A somatic cell approach of the genetic analysis of the laboratory mouse. J. Exp. Zool. 187:303-308.

22. Kozak, C., E. Nichols, and F. H. Ruddle. 1975. Gene linkage analysis in the mouse by somatic cell hybridization: assignment of adenine phosphoribosyl transferase to chromosome 8 and alpha-galactosidase to the $\mathrm{X}$ chromosome. Somatic Cell Genet. 1:371-382.

23. Kozak, C., and W. P. Rowe. 1978. Genetic mapping of xenotropic leukemia virus-inducing loci in two mouse strains. Science 199:1448-1449.

24. Kozak, C., and W. P. Rowe. 1979. Genetic mapping of the ecotropic murine leukemia virus-inducing locus of the BALB/c mouse to chromosome 5. Science 204:6971.

25. Kozak, C. A., and F. H. Ruddle. 1976. Sexual and parasexual approaches to the genetic analysis of the laboratory mouse, Mus musculus. In Vitro 12:720-725.

26. Marshall, T. H., and U. R. Rapp. 1979. Genes controlling receptors for ecotropic and xenotropic type $\mathrm{C}$ virus in Mus cervicolor and Mus musculus. J. Virol. 29:501506.

27. Morris, V. L., C. Kozak, J. C. Cohen, P. R. Shank, P. Jolicoeur, F. Ruddle, and H. E. Varmus. 1979. Endogenous mouse mammary tumor virus DNA is distrib- uted among multiple mouse chromosomes. Virology 92: $46-55$.

28. Oie, H. K., A. F. Gazdar, P. A. Lalley, E. K. Russell, J. D. Minna, J. DeLarco, G. J. Todaro, and U. Francke. 1978. Mouse chromosome 5 codes for ecotropic murine leukemia virus cell-surface receptor. $\mathrm{Na}$ ture (London) 274:60-62.

29. Rasheed, S., M. B. Gardner, and E. Chan. 1976. Amphotropic host range of naturally occurring wild mouse leukemia viruses. J. Virol. 19:13-18.

30. Robbins, K. C., C. D. Cabradilla, J. R. Stephenson, and S. A. Aaronson. 1977. Segregation of genetic information for a B-tropic leukemia virus with the structural locus for BALB:virus 1. Proc. Natl. Acad. Sci. U.S.A. 74:2953-2957.

31. Rowe, W. P. 1973. Genetic factors in the natural history of murine leukemia virus infection: G. H. A. Clowes memorial lecture. Cancer Res. 33:3061-3068.

32. Rowe, W. P., J. W. Hartley, and T. Bremmer. 1972. Genetic mapping of a murine leukemia virus-inducing locus of AKR mice. Science 178:860-862.

33. Rowe, W. P., J. B. Humphrey, and F. Lilly. 1973. A major locus affecting resistance to infection with murine leukemia viruses. III. Assignment of the Fv-1 locus to linkage group VIII of the mouse. J. Exp. Med. 137:850853.

34. Ruddle, N. H., B. S. Conta, L. Leinwand, C. Kozak, F. Ruddle, P. Besmer, and D. Baltimore. 1978. Assignment of the receptor for ecotropic murine leukemia virus to mouse chromosome 5. J. Exp. Med. 148:451465.

35. Southern, E. M. 1975. Detection of specific sequences among DNA fragments separated by gel electrophoresis. J. Mol. Biol. 98:503-517.

36. Steffen, D., S. Bird, W. P. Rowe, and A. Weinberg. 1979. Identification of DNA fragments carrying ecotropic proviruses of AKR mice. Proc. Natl. Acad. Sci. U.S.A. 76:4554-4558.

37. Steffen, D., and R. A. Weinberg. 1978. The integrated genome of murine leukemia virus. Cell 15:1003-1010.

38. Taylor, J. M., R. Illmensee, and J. Summers. 1976. Efficient transcription of RNA into DNA by avian sarcoma virus polymerase. Biochim. Biophys. Acta 442: 324-330.

39. Todaro, G. J., and R. J. Huebner. 1972. The viral oncogene hypothesis: new evidence. Proc. Natl. Acad. Sci. U.S.A. 69:1009-1015

40. Wiener, F., S. Ohno, J. Spira, N. Haran-Ghera, and G. Klein. 1978. Cytogenic mapping of the trisomic segment of chromosome 15 in murine T-cell leukemia. Nature (London) 275:658-660.

41. Yoshikura, H. 1973. A genetic model of the host range restriction of murine leukemia viruses. A review and a hypothesis. Jpn. J. Exp. Med. 43:1-7. 